\title{
Neurokinin 3 Receptor Antagonists Compared With Serotonin Norepinephrine Reuptake Inhibitors for Non-Hormonal Treatment of Menopausal Hot Flushes: A Systematic Qualitative Review
}

\author{
Sara J. Menown · Javier A. Tello iD
}

Received: July 20, 2021 / Accepted: August 19, 2021 / Published online: September 12, 2021

(c) The Author(s) 2021

\begin{abstract}
Introduction: Hot flushes/flashes (HFs) or other vasomotor symptoms affect between 45 and $97 \%$ of women during menopause. Hormone replacement therapy (HRT) is effective at alleviating menopausal symptoms, but some women cannot or prefer not to take HRT. Since current non-hormonal options have suboptimal efficacy/tolerability, there is a pressing need for an effective, well-tolerated alternative. The neurokinin 3 receptor (NK3R) has recently been implicated in the generation of menopausal HFs and represents a novel therapeutic target to ameliorate HF symptoms. This review aims to
\end{abstract}

S. J. Menown · J. A. Tello $(\bowtie)$

School of Medicine, University of St Andrews, Medical and Biological Sciences Building, North Haugh, St Andrews KY16 9TF, UK

e-mail: jt65@st-andrews.ac.uk

J. A. Tello

Biomedical Research Complex, University of St Andrews, North Haugh, St Andrews KY16 9TZ, UK

J. A. Tello

Centre for Biophotonics, University of St Andrews,

North Haugh, St Andrews KY16 9SS, UK

Present Address:

S. J. Menown

School of Medicine, Dentistry and Nursing, College of Medical, Veterinary \& Life Sciences, University of Glasgow, Glasgow, Scotland

e-mail: sjmenown@gmail.com assess if NK3R antagonists (NK3Ras) are more effective than Serotonin Norepinephrine Reuptake Inhibitors (SNRIs) - currently a common choice for non-hormonal treatment of menopausal HFs.

Methods: Studies were identified after systematically searching Ovid MEDLINE and EMBASE databases based on PRISMA guidelines. Trial quality and bias were assessed. Key efficacy outcomes (HF frequency, HF severity and number of night-time awakenings/nightsweats) and selected safety outcomes were extracted and analysed.

Results: Seven SNRI and four NK3Ra placebocontrolled randomised trials (plus four followup reports) were included in this review. NK3Ra administration resulted in a larger reduction from baseline in HF frequency, HF severity and night-sweats compared to SNRIs. Five of seven SNRI trials showed a reduction in HF frequency that was statistically significant (by 48-67\% from baseline at weeks 8 or 12) whereas all NK3Ra trials showed a statistically significant reduction in HF frequency (by 62-93\% from baseline at weeks 2,4 or 12). While SNRI trials reported poor tolerability, particularly nausea, NK3Ra trials reported good tolerability overall, although two trials reported elevation in transaminases.

Conclusion: NK3Ras trials show encouraging efficacy and tolerability/safety. Completion of phase 3 NK3Ra trials are required to confirm efficacy and uphold safety/tolerability data but 
phase 2 results suggest that NK3Ras are more effective than SNRIs for non-hormonal treatment of menopausal HFs.

Keywords: Menopause; Vasomotor symptoms; Hot flushes/flashes; Neurokinin 3 receptor antagonist; Fezolinetant; Elinzanetant (NT814); MLE4901; Serotonin Norepinephrine Reuptake Inhibitor; Venlafaxine; Desvenlafaxine

\section{Key Summary Points}

Between 45 and $97 \%$ of menopausal women suffer vasomotor symptoms (hot flushes/flashes and night-sweats) which can significantly impact their quality of life and $10-20 \%$ find them almost intolerable.

Conventional treatment is hormone replacement therapy (HRT) but some women cannot or prefer not to take HRT. However, current non-hormonal options have suboptimal efficacy and tolerability.

Neurokinin B, predominantly acting via the neurokinin 3 receptor (NK3R), has been implicated in the generation of menopausal hot flushes/flashes.

We undertook a systematic qualitative review to compare outcomes of placebocontrolled randomised clinical trials using neurokinin 3 receptor antagonists (NK3Ras) with those using Serotonin Norepinephrine Reuptake Inhibitors (SNRIs) for the non-hormonal treatment of menopausal hot flushes/flashes.

NK3Ra trials reported numerically superior efficacy and better safety/tolerability compared with SNRIs trials. Provided that phase 3 NK3Ra trials are supportive, NK3Ras appear a promising therapy for this challenging area.

\section{INTRODUCTION}

Hot flushes/flashes (HFs), defined as transient sensations of heat, flushing, sweating and chills, affect between 45 and $97 \%$ of women during menopause and can significantly degrade their quality of life [1]. HFs often lead to sleep disturbances for a prolonged period, with recurrent episodes occurring over a median duration of 7.4 years [2]. Between 10 and $20 \%$ of women find HFs almost intolerable [3]. While the full pathophysiological mechanism of HFs remains elusive, oestrogen deficiency appears to play a causative role. Hormone replacement therapy (HRT) remains the most commonly prescribed treatment to alleviate menopausal symptoms provided there are no contraindications (Table 1) [4]. However, the use of HRT has decreased after reports of increased risk of cardiovascular $(\mathrm{CV})$ disease, breast cancer, stroke and pulmonary embolism [5]. While subsequent data suggest that the benefits of HRT typically outweigh the risks for women without contraindications, many now seek non-hormonal alternatives.

Table 1 Typical contraindications for hormone replacement therapy [4]

Contraindications for hormone replacement therapy

Current, past, or suspected breast cancer

Known or suspected oestrogen-dependent cancer

Undiagnosed vaginal bleeding

Untreated endometrial hyperplasia

Previous idiopathic or current venous thromboembolism (deep vein thrombosis or pulmonary embolism), unless the woman is already on anticoagulant treatment

Active or recent arterial thromboembolic disease (for example, angina or myocardial infarction)

Active liver disease with abnormal liver function tests Pregnancy

Thrombophilic disorder 


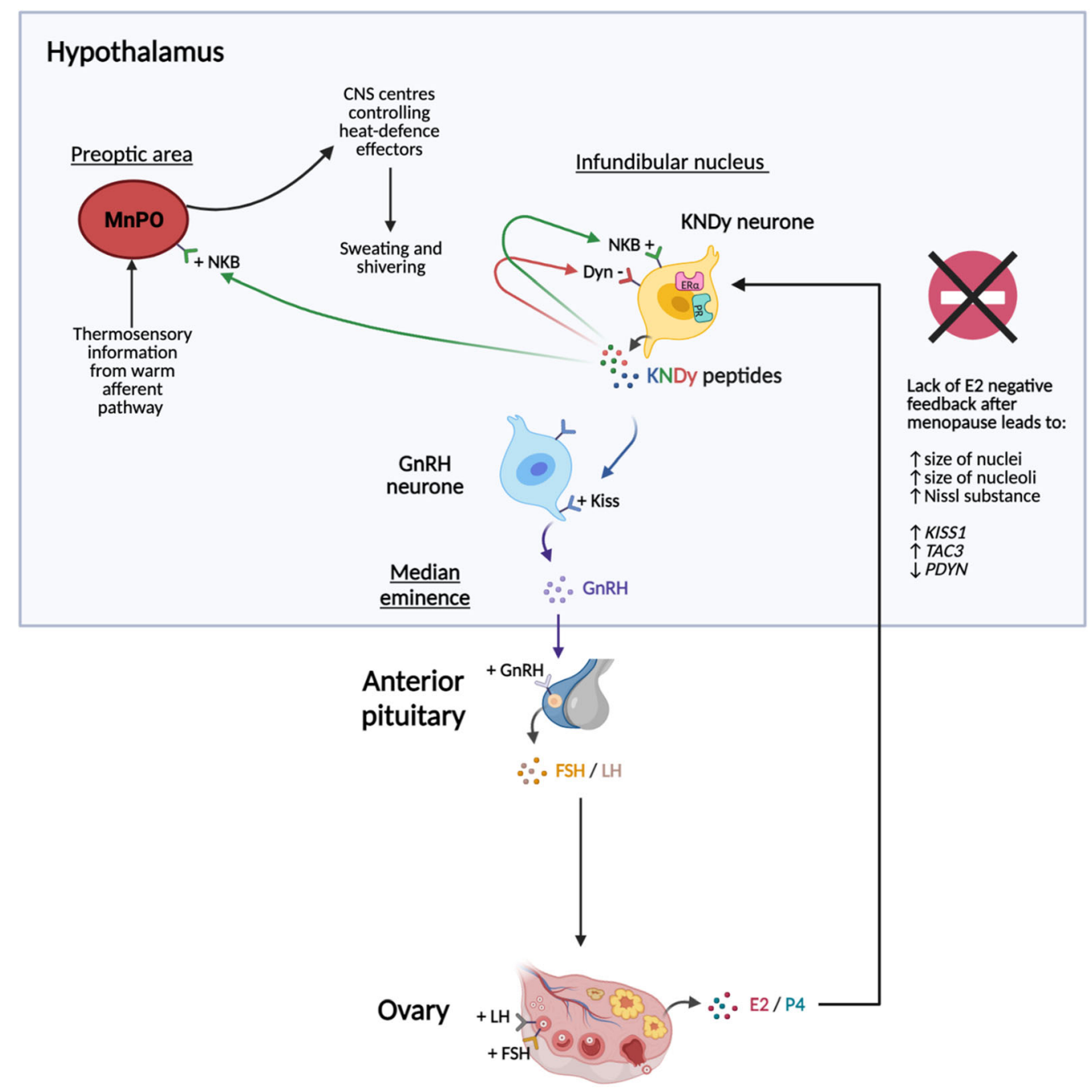

Fig. 1 Relationship between KNDy neurons, GnRH neurons, and the heat-defence pathway. KNDy neurones in the infundibular nucleus secrete the neuropeptides Kiss (encoded by the KISS1 gene), NKB (encoded by the $T A C 3$ gene) and Dyn (encoded by the PDYN gene). NKB and Dyn act autosynaptically, stimulating and inhibiting further Kiss release, respectively. Kiss acts on $\mathrm{GnRH}$ neurones. GnRH stimulates LH and FSH release from the anterior pituitary which stimulates ovarian sex steroid production. During menopause, lack of oestradiol (E2) negative feedback results in increased expression of KISSI and TAC3 mRNA but decreased expression of PDYN mRNA. Consequently, KNDy neurones become hypertrophied, as seen by increased size of nuclei/nucleoli and increased Nissl substance. KNDy neurones project to the

Current non-hormonal treatment options include Serotonin Norepinephrine Reuptake Inhibitors (SNRIs) or Selective Serotonin hypothalamic thermoregulatory centre (the median POA and adjacent $\mathrm{MnPO}$ ). During menopause, the increase in $\mathrm{NKB}$ signalling and overstimulation of KNDy neurons increases activity in the thermoregulatory centre which then becomes hypersensitive to external cues from peripheral sensors, leading to activation of heat dissipation effectors. KNDy kisspeptin-neurokinin B-dynorphin, Kiss kisspeptin, $N K B$ neurokinin B, Dyn dynorphin, GnRH gonadotropin-releasing hormone, $L H$ luteinizing hormone, FSH follicle-stimulating hormone, POA pre-optic area, $M n P O$ median preoptic nucleus, E2 oestradiol, $E R \alpha$ oestrogen receptor alpha, $P R$ progesterone receptor, KISSI kisspeptin gene, TAC3 tachykinin 3 gene, $P D Y N$ prodynorphin gene. The figure was created with BioRender.com

Reuptake Inhibitors (SSRIs), clonidine, gabapentin and pregabalin. Of these, SNRIs/SSRIs are probably the most commonly recommended 
[6], with data for venlafaxine considered the most convincing [7]. Nevertheless, none of the current non-hormonal drugs have optimal efficacy and use in clinical practice may be limited by side effects or by interactions with other medications (for example, paroxetine or other CYP2D6 inhibitors should not be co-prescribed with tamoxifen [7] which is clinically relevant considering that a key indication for a nonhormonal treatment is prior breast cancer). Therefore, there remains a pressing need for an effective and well-tolerated nonhormonal alternative.

The hypothalamic neuropeptide kisspeptin (Kiss; encoded by the KISS1 gene) is required for human fertility being a potent stimulator of the hypothalamic-pituitary-gonadal axis (Fig. 1) [8]. In primates, a population of Kiss neurones located in the hypothalamic infundibular nucleus co-express the neuropeptides, neurokinin B (NKB) and dynorphin (Dyn), and are thus termed kisspeptin-neurokinin B-dynorphin (KNDy) neurones [9]. NKB [encoded by the tachykinin 3 (TAC3) gene] and Dyn [encoded by the prodynorphin $(P D Y N)$ gene] regulate pulsatile Kiss secretion from KNDy neurones by acting auto-synaptically via neurokinin 3 receptors (NK3R) and Dyn (kappa opioid) receptors to stimulate and inhibit the release of Kiss, respectively [10]. KNDy neurones project to the hypothalamic thermoregulatory centre in mammals (the median preoptic area and adjacent median preoptic nucleus) [11]. Gonadal feedback is transmitted by oestrogen receptor alpha $(\mathrm{ER} \alpha)$ and progesterone receptors (PR) expressed on Kiss neurons. KNDy neurones are normally stimulated by NK3R activation and inhibited by oestrogen. However, during menopause declining oestrogen levels leads to NKB hypersecretion, and overstimulation of KNDy neurons in particular. This elicits increased activity in the thermoregulatory centre, which shifts the thermoneutral zone increasing sensitivity to external cues and triggering more frequent heat dissipation responses such as HFs [12].

Blockade of NKB signalling with the use of an NK3R antagonist (NK3Ra) is proposed to normalise KNDy neurone activity and thus may help alleviate HFs in menopausal women. This review aimed to (1) evaluate randomised controlled trials (RCTs) reporting the efficacy and tolerability of NK3Ras for the treatment of menopausal HFs and (2) to put these findings in clinical context by qualitative comparison with outcome data from RCTs using the SNRI venlafaxine (or the succinate salt of its active metabolite, desvenlafaxine) to treat menopausal HFs.

\section{METHODS}

To put the clinical outcomes of the NK3Ra studies into context, a clinically relevant alternative non-hormonal therapy was required for comparison. While arguments could be made for selecting any one of the SNRIs/SSRIs, clonidine, gabapentin or pregabalin, multiple guidelines and reviews suggest that SSRIs/SNRIs are the most commonly recommended [6], with trial evidence strongest for venlafaxine/desvenlafaxine, paroxetine and citalopram/escitalopram [13]. Of these, venlafaxine (or its active metabolite desvenlafaxine) was selected for 3 reasons: modest current use was confirmed after consultation with each of 4 UK regional menopause clinics (London, Edinburgh, Cardiff and Belfast), a College report considered the most convincing SSRI/SNRI efficacy data were for venlafaxine [7], and, since venlafaxine does not interact with tamoxifen, it is the preferred treatment for breast cancer survivors taking tamoxifen [14], a key indication for a non-hormonal menopause treatment. In contrast, the SSRI paroxetine is a potent CYP2D6 inhibitor and is contra-indicated with tamoxifen. The SSRI fluoxetine and SNRI duloxetine are also CYP2D6 inhibitors (albeit more moderate).

A systematic search of the published literature up to $17 / 2 / 2021$ was undertaken on Ovid MEDLINE and EMBASE, based on PRISMA guidelines [15] and using the following key words: "venlafaxine", "desvenlafaxine", "hot flushes", "hot flashes", "vasomotor symptoms", "VMS", "menopause", "neurokinin B", "dynorphin", "kisspeptin", "kappa", "neurokinin 1", "neurokinin 3", "neurokinin B". Further studies were identified by cross-referencing references from the qualifying studies. Duplicates were 
removed and studies were screened using inclusion/exclusion criteria.

Inclusion criteria were: studies of perimenopausal, menopausal and postmenopausal women (natural or surgically induced only), having HFs, receiving NK3Ra or venlafaxine/ desvenlafaxine treatment, comparison with a placebo arm, frequency and severity of HFs reported, primary research design and in English language.

Exclusion criteria were: pre-menopausal women, chemically or medically induced menopause, not having HFs, not receiving treatment with NK3Ra or venlafaxine/desvenlafaxine, or receiving treatment for HFs in addition to NK3Ra or venlafaxine/desvenlafaxine. Qualifying studies were required to meet all inclusion criteria and studies discarded if they met any one of the exclusion criteria.

Only women with natural or surgically-induced menopause were included to ensure a definitive and irreversible diagnosis. Women with medically-induced menopause (such as chemotherapy or use of GnRH analogues) were excluded, as their ovarian function may have had the potential to recover (and reverse menopause). Men were excluded due to the different physiology involved in the development of HFs.

Women concurrently receiving any other medications to relieve HFs other than the study drugs were excluded so that the measured effect could be attributed solely to the drugs under investigation.

A large placebo effect is well described in HF treatment trials [16], thus only studies comparing the active drug versus placebo were selected so that the drug's effect could be evaluated in context.

Once qualifying studies were identified, study quality was assessed using Critical Appraisal Skills Programme (CASP) methodology [17]. The CASP method evaluated four main components (study design, methodology, reporting of results and clinical implications), with each component addressed by either 2 or 3 questions. The Cochrane Collaboration's tool [18] was used to assess for risk of bias in each study, comprising 7 questions defined by the Cochrane handbook to evaluate selection (randomisation or allocation concealment), reporting, performance, detection, attrition and other bias. One author (S.J.M.) undertook the primary detailed evaluation of quality and bias for each study. Equivocal findings were discussed with a second author (J.A.T.) to reach consensus.

To enable comparison of SNRI and NK3Ra outcomes, while studies may include different outcome measures [19], each qualifying study was assessed for the specific key efficacy outcomes of HF frequency, HF severity and, if stated, night-time awakenings due to HFs, plus safety/tolerability outcomes including common adverse events (AEs), serious adverse events (SAE) and discontinuation due to AEs. Since SNRI studies were phase 3 whereas NK3Ra trials were phase 2 , a systematic qualitative review rather than a meta-analysis was considered the most appropriate.

This paper is based on previously published data and does not involve any new studies with human or animal subjects performed by any of the authors.

\section{RESULTS}

Figure 2 illustrates the PRISMA flow diagram summarising the search process. The initial search yielded 651 records. After 127 duplicates were removed, 524 studies were screened for inclusion (based on the inclusion/exclusion criteria). A total of 500 studies were excluded based on the title or abstract. The remaining 24 studies required assessment of the full text, and a further three studies were found by cross-referencing references from these studies. This resulted in 15 qualifying studies for qualitative synthesis (seven SNRI trials plus two follow-up papers [20-28] and four NK3Ra trials plus two follow-up papers [29-34]).

Table 2 summarises the CASP quality assessment for each study. For illustrative purposes, when assessing the four components, if all answers were 'Yes', the score was designated as 'high' quality of evidence (green). If one or more answers was ' $\mathrm{No}^{\prime}$ ', the score was assigned as 'low' quality of evidence (red). If one or more answers was 'cannot tell' (but none was 'no') 

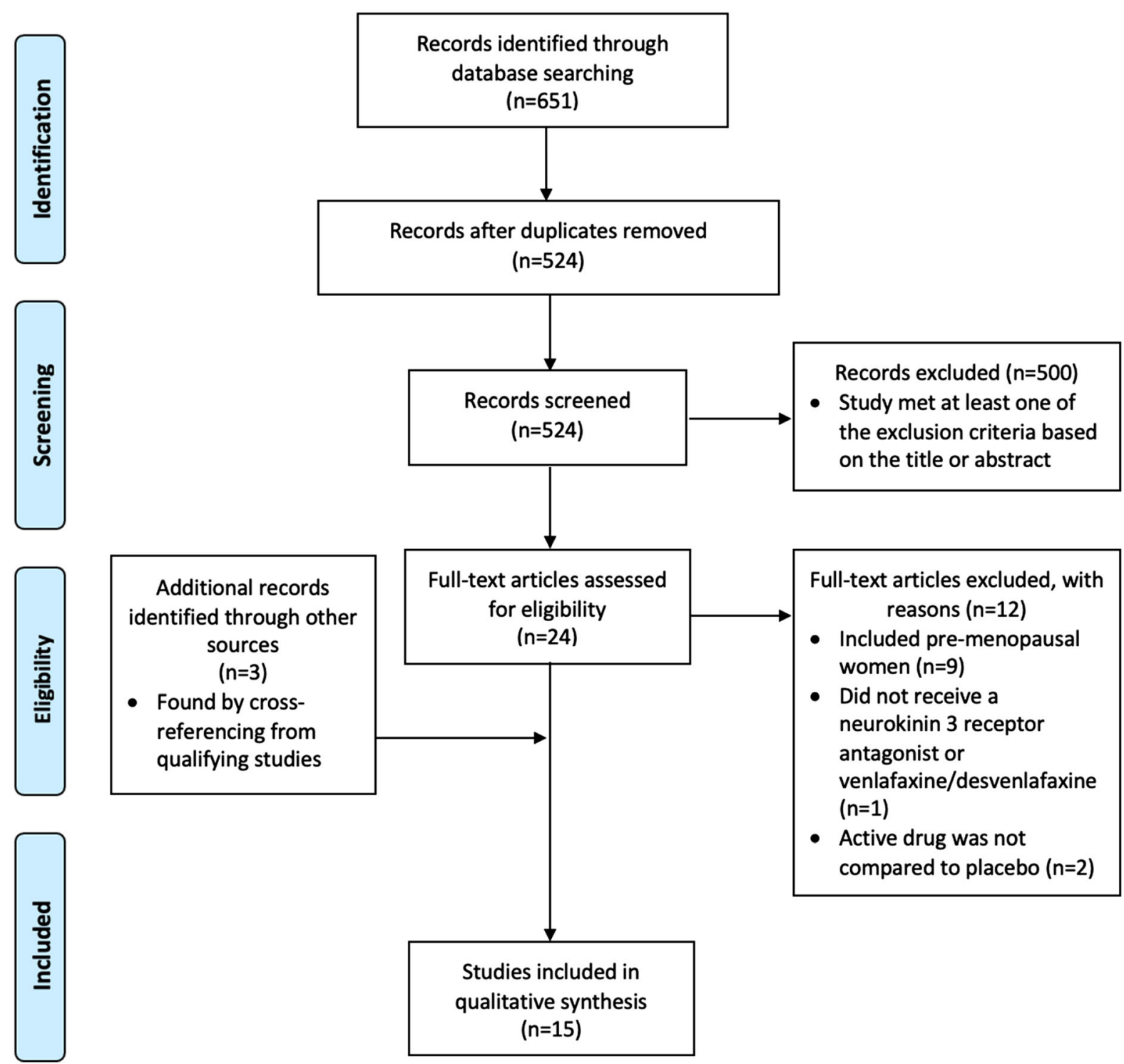

Fig. 2 PRISMA flow diagram summarising the search strategy used to identify qualifying studies [15]

the score was assigned as 'unclear' quality of evidence (orange). The full quality analysis for each study is available upon request. Overall, the studies were mostly of high quality.

Table 3 summarises the Cochrane Collaboration's tool bias assessment for each study. For illustrative purposes, a low risk of bias subtype was shown as green, a high risk as red and an unclear risk as orange. The full quality analysis for each study is available upon request. Overall, the studies were mostly of low bias.

Table 4 summarises the study design, efficacy and tolerability/safety outcomes for SNRI trials. Overall, the SNRI trials showed modest HF reduction. There was a statistically significant 
Table 2 Quality of evidence summary for (A) SNRI and (B) NK3Ra studies, assessed using Critical Appraisal Skills Programme checklists [17]

\begin{tabular}{|c|c|c|c|c|c|c|c|c|c|c|c|c|c|c|c|}
\hline & \multicolumn{9}{|c|}{ (A) SNRI studies } & \multicolumn{6}{|c|}{ (B) NK3Ra studies } \\
\hline $\begin{array}{l}=\text { High quality of evidence } \\
=\text { Low quality of evidence } \\
=\text { Unclear quality of evidence }\end{array}$ & 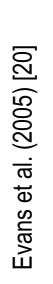 & 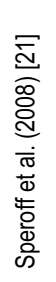 & 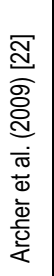 & 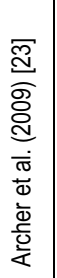 & 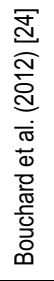 & 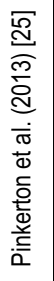 & 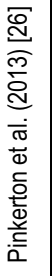 & 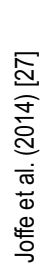 & 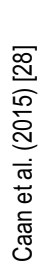 & 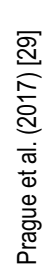 & 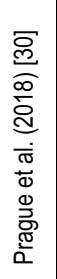 & 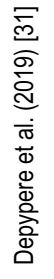 & 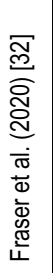 & 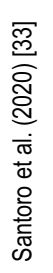 & 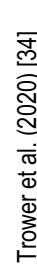 \\
\hline \multicolumn{16}{|l|}{$\begin{array}{l}\text { Is the basic study design valid for a randomised } \\
\text { controlled trial? }\end{array}$} \\
\hline $\begin{array}{l}\text { Did the study address a clearly focused } \\
\text { research question? }\end{array}$ & $\checkmark$ & $\checkmark$ & $\checkmark$ & $\checkmark$ & $\checkmark$ & $\checkmark$ & $\checkmark$ & $\checkmark$ & $\checkmark$ & $\checkmark$ & $\checkmark$ & $\checkmark$ & $\checkmark$ & $\checkmark$ & $\checkmark$ \\
\hline $\begin{array}{l}\text { Was the assignment of participants to } \\
\text { interventions randomised? }\end{array}$ & $\checkmark$ & $\checkmark$ & $\checkmark$ & $\checkmark$ & $\checkmark$ & $\checkmark$ & $\checkmark$ & $\checkmark$ & $\checkmark$ & $\checkmark$ & $\checkmark$ & $\checkmark$ & $\checkmark$ & $\checkmark$ & $\checkmark$ \\
\hline $\begin{array}{l}\text { Were all participants who entered the study } \\
\text { accounted for at its conclusion? }\end{array}$ & $x$ & $\checkmark$ & $\checkmark$ & $\checkmark$ & $\checkmark$ & $\checkmark$ & $\checkmark$ & $\checkmark$ & $\checkmark$ & $\checkmark$ & $\checkmark$ & $\checkmark$ & $\checkmark$ & $\checkmark$ & $\checkmark$ \\
\hline \multicolumn{16}{|l|}{ Was the study methodologically sound? } \\
\hline $\begin{array}{l}\text { Were the participants, investigators and } \\
\text { people assessing/analysing blinded? }\end{array}$ & $?$ & $\checkmark$ & $\checkmark$ & $\checkmark$ & $\checkmark$ & $\checkmark$ & $\checkmark$ & $\checkmark$ & $\checkmark$ & $\checkmark$ & $\checkmark$ & $\checkmark$ & $\checkmark$ & $\checkmark$ & $\checkmark$ \\
\hline $\begin{array}{l}\text { Were the study groups similar at the start of } \\
\text { the randomised controlled trial? }\end{array}$ & $x$ & $\checkmark$ & $\checkmark$ & $\checkmark$ & $\checkmark$ & $\checkmark$ & $\checkmark$ & $\checkmark$ & $\checkmark$ & $\checkmark$ & $\checkmark$ & $\checkmark$ & $\checkmark$ & $\checkmark$ & $\checkmark$ \\
\hline $\begin{array}{l}\text { Did each study group receive the same level } \\
\text { of care? }\end{array}$ & $\checkmark$ & $\checkmark$ & $\checkmark$ & $\checkmark$ & $\checkmark$ & $\checkmark$ & $\checkmark$ & $\checkmark$ & $\checkmark$ & $\checkmark$ & $\checkmark$ & $\checkmark$ & $\checkmark$ & $\checkmark$ & $\checkmark$ \\
\hline \multicolumn{16}{|l|}{ What are the results? } \\
\hline $\begin{array}{l}\text { Were the effects of intervention reported } \\
\text { comprehensively? }\end{array}$ & $x$ & $x$ & $x$ & $x$ & $\checkmark$ & $\checkmark$ & $\checkmark$ & $\checkmark$ & $\checkmark$ & $\checkmark$ & $\checkmark$ & $x$ & $\checkmark$ & $\checkmark$ & $\checkmark$ \\
\hline $\begin{array}{l}\text { Was the precision of the estimate of the } \\
\text { intervention effect reported? }\end{array}$ & $\checkmark$ & $\checkmark$ & $\checkmark$ & $\checkmark$ & $\checkmark$ & $\checkmark$ & $\checkmark$ & $\checkmark$ & $\checkmark$ & $\checkmark$ & $\checkmark$ & $\checkmark$ & $\checkmark$ & $\checkmark$ & $\checkmark$ \\
\hline $\begin{array}{l}\text { Do the benefits of the intervention outweigh } \\
\text { the harms and costs? }\end{array}$ & $?$ & $\checkmark$ & $\checkmark$ & $\checkmark$ & $?$ & $\checkmark$ & $\checkmark$ & $\checkmark$ & $\checkmark$ & $\checkmark$ & $\checkmark$ & $\checkmark$ & $\checkmark$ & $\checkmark$ & $\checkmark$ \\
\hline \multicolumn{16}{|l|}{ Will the results help locally? } \\
\hline $\begin{array}{l}\text { Can the results be applied to your local } \\
\text { population/in your context? }\end{array}$ & $\checkmark$ & $?$ & $?$ & $?$ & $?$ & $?$ & $?$ & $\checkmark$ & $\checkmark$ & $?$ & $?$ & $?$ & $?$ & $?$ & $?$ \\
\hline $\begin{array}{l}\text { Would the intervention provide greater value } \\
\text { than any existing intervention? }\end{array}$ & $x$ & $\checkmark$ & $\checkmark$ & $\checkmark$ & $?$ & $\checkmark$ & $\checkmark$ & $\checkmark$ & $\checkmark$ & $?$ & $?$ & $?$ & $?$ & $?$ & $?$ \\
\hline
\end{tabular}

reduction in $\mathrm{HF}$ frequency versus placebo in five of seven trials $[21-23,25,27](48-67 \%$ reduction from baseline at week 8 or 12 in the setting of a $25-51 \%$ placebo response) and a statistically significant reduction in HF severity versus placebo in five of seven trials $[21-23,25,27]$ for at least one dose and one time point (24-31\% reduction from baseline at week 12 in the setting of a $12-18 \%$ placebo response where percentage data were reported). Night-time awakenings due to HFs showed a statistically significant reduction in the three trials [21-23] that measured this outcome $(53-77 \%$ reduction from baseline at week 12 in the setting of
44-63\% placebo response). However, HF frequency and HF severity did not show a statistically significant reduction versus placebo in two SNRI trials [20, 24]. SNRI-treated subjects experienced more AEs (in all trials) and discontinuations due to AEs (in all but one trial [22]) versus placebo. Common AEs included nausea, dry mouth, insomnia, dizziness and constipation (with nausea being reported to be the most debilitating).

Table 5 summarises the study design efficacy and tolerability/safety outcomes for NK3Ra trials. 
Table 3 Risk of bias summary for the (A) SNRI and (B) NK3Ra studies, assessed using the Cochrane Collaboration's tool [18]

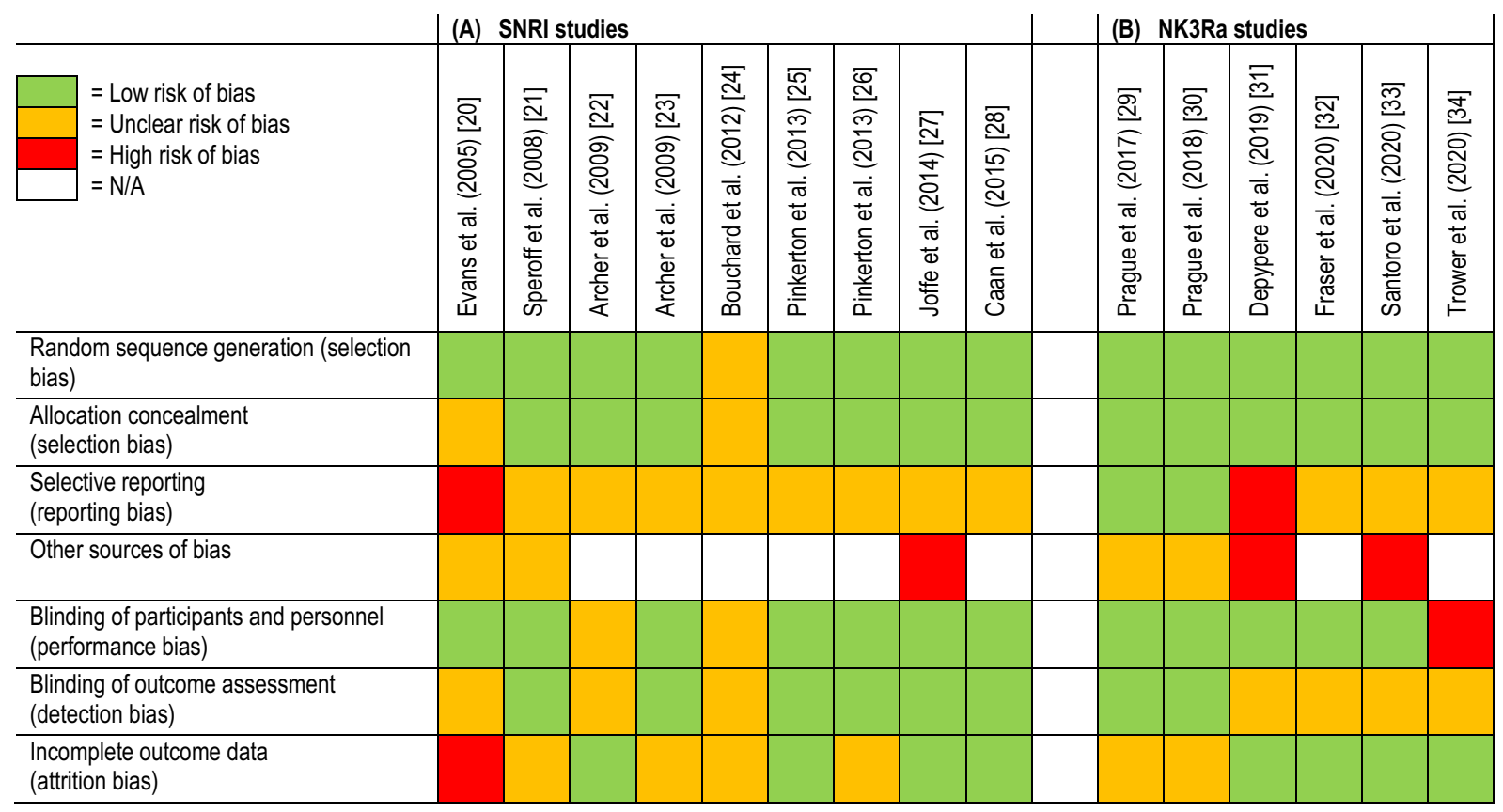

Overall, in comparison to SNRI trials, the NK3Ra trials reported a larger reduction versus baseline in HF outcomes. NK3Ras led to a statistically significant reduction in HF frequency versus placebo at all time points, across all four trials, apart from the two lowest doses in the dose-ranging study by Trower et al. [34] (62-93\% reduction from baseline at weeks 2,4 or 12 in the setting of a $28-55 \%$ placebo response). HF severity also showed a reduction versus placebo in all trials (41-94\% reduction from baseline measured at weeks 2,4 or 12 in the setting of a $5-46 \%$ placebo response), although not all doses reached significance at all time points in the two dose-ranging trials $[32,34]$. The number of night-time HFs/frequency of waking due to night-sweats showed a statistically significantly reduction versus placebo in the two trials $[30,34]$ that measured this outcome $(63-81 \%$ reduction from baseline at weeks 2 and 4 in the setting of a 22-32\% placebo response).

\section{DISCUSSION}

In this qualitative analysis, NK3Ras reported larger reductions from baseline compared to SNRIs in terms of HF frequency, HF severity and night-sweats. All four NK3Ra trials reported statistically significant reductions in HF frequency by $62-93 \%$ from baseline at weeks 2,4 or 12 (in the setting of a $28-55 \%$ placebo response), whereas only five of seven SNRI trials reported reduced HF frequency by $48-67 \%$ from baseline at weeks 8 or 12 (in the setting of a $25-51 \%$ placebo response) and two of seven trials reported no significant reduction. NK3Ra trials reported generally good tolerability (although transaminases elevation was noted in two trials) whereas SNRI trials reported less favourable tolerability, with nausea being common.

\section{Trial Strengths and Weaknesses}

While both the SNRI and NKR3a trials had many strengths, potential limitations were 
Table 4 Serotonin-norepinephrine reuptake inhibitor (SNRI) study results

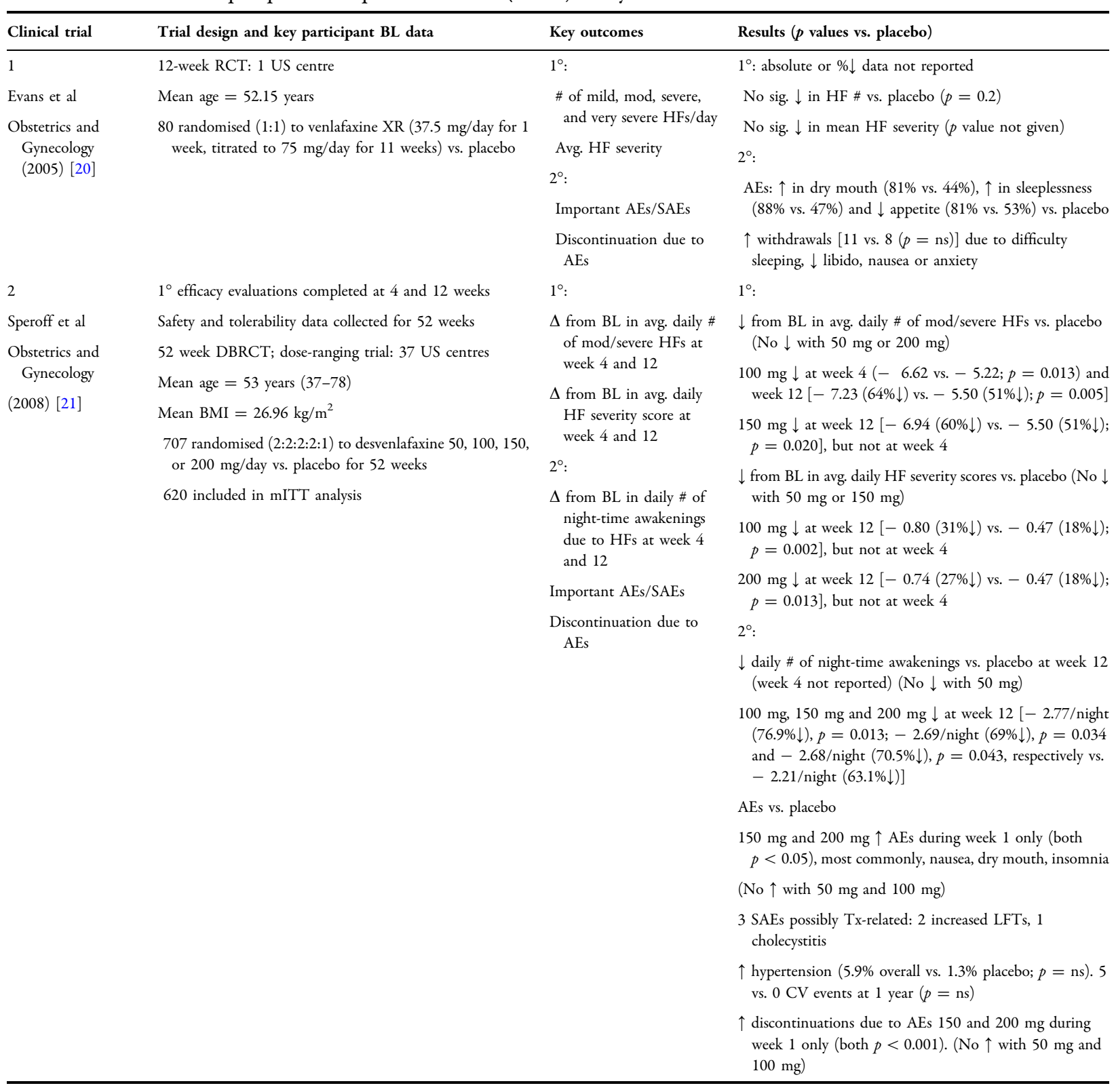


Table 4 continued

\begin{tabular}{|c|c|c|c|}
\hline Clinical trial & Trial design and key participant BL data & Key outcomes & Results ( $p$ values vs. placebo) \\
\hline 3 & 12 week DBRCT: 34 US centres & $1^{\circ}:$ & $1^{\circ}:$ \\
\hline $\begin{array}{l}\text { Archer et al } \\
\text { American Journal of } \\
\text { Obstetrics and } \\
\text { Gynecology } \\
\text { (2009) [22] }\end{array}$ & $\begin{array}{l}\text { Mean age }=53.36 \text { years }(29-71) \\
\text { Mean } \mathrm{BMI}=27.86 \mathrm{~kg} / \mathrm{m}^{2}(17.2-40.1) \\
458 \mathrm{randomised} \text { to desvenlafaxine } 100 \mathrm{mg} / \text { day or } \\
150 \mathrm{mg} / \text { day vs. placebo for } 12 \text { weeks }[50 \mathrm{mg} / \text { day for } \\
3 \text { days, titrated to } 100 \mathrm{mg} / \text { day on day } 4 \text { (titrated to } \\
150 \mathrm{mg} / \text { day on day } 8 \text { for } 150 \mathrm{mg} / \text { day group)] } \\
2 \text { week dose-tapering } \\
436 \text { included in mITT analysis }\end{array}$ & $\begin{array}{l}\Delta \text { from BL in avg. daily \# } \\
\text { mod/severe HFs at } \\
\text { weeks } 4 \text { and } 12 \\
\Delta \text { from BL in avg. daily } \\
\text { HF severity score at } \\
\text { weeks } 4 \text { and } 12 \\
2^{\circ} \text { : } \\
\Delta \text { from BL in \# of night- } \\
\text { time awakenings at } \\
\text { weeks } 4 \text { and } 12 \\
\text { Important AEs/SAEs } \\
\text { Discontinuation due to } \\
\text { AEs }\end{array}$ & $\begin{array}{l}\downarrow \text { daily \# of HF from BL vs. placebo with } 100 \mathrm{mg} \text { and } \\
150 \mathrm{mg} \text { at week } 4 \text { (both } p \leq 0.012, \text { no } \% \text { given) and } \\
\text { week } 12(65.4 \% \downarrow, p=0.005 \text {; and } 66.6 \% \downarrow, p=0.012 \text {, } \\
\text { respectively vs. } 50.8 \% \downarrow) \\
\downarrow \text { daily HF severity score from BL vs. placebo with } 100 \mathrm{mg} \\
\text { and } 150 \mathrm{mg} \text { at week } 12[-0.65(27 \% \downarrow) \text {; and }-0.66 \\
(27.5 \% \downarrow) \text {, respectively vs. }-0.33(13.75 \% \downarrow) \text {; both } \\
p<0.001] \text {, and at all other time points } \\
2^{\circ} \text { : } \\
\downarrow \text { daily \# of night-time awakenings from BL vs. placebo } \\
\text { with } 100 \text { mg and } 150 \text { mg at week } 4(-1.8 \text { and }-1.6 \text {, } \\
\text { respectively vs. }-1.2) \text { and week } 12[-2.0(60.6 \% \downarrow) \text { and } \\
-1.8(58.1 \% \downarrow) \text {, respectively vs. }-1.4(43.8 \% \downarrow)] \text {; all } \\
p \leq 0.048 \\
\uparrow \text { AEs during week } 1 \text { only vs. placebo }(84.1 \% \text { vs. } 69.5 \% \text {; } \\
p=0.002) \text {, most commonly nausea }(25.2 \%) \text {, dry mouth, } \\
\text { insomnia, constipation, asthenia } \\
2 \text { SAEs possibly Tx-related: hypertension }(1 \text { subject with } \\
150 \text { mg } \uparrow \text { SBP by } 4.52 \text { mmHg at week } 12(p=0.002) \text {, } \\
\text { bronchospasm }(1 \text { subject but on placebo) } \\
\text { Discontinuation due to AEs: no diff. [but numerically } \uparrow \text { in } \\
150 \text { mg group ( } p=\text { ns)] }\end{array}$ \\
\hline 4 & 26 week DBRCT: 32 US centres & $1^{\circ}:$ & $1^{\circ}:$ \\
\hline $\begin{array}{l}\text { Archer et al } \\
\text { American Journal of } \\
\text { Obstetrics and } \\
\text { Gynecology } \\
\text { (2009) [23] }\end{array}$ & $\begin{array}{l}\text { Mean age }=53.7 \text { years } \\
\text { Mean } \mathrm{BMI}=27.1 \mathrm{~kg} / \mathrm{m}^{2}(15.9-40.4) \\
567 \mathrm{randomised} \text { to desvenlafaxine } 100 \mathrm{mg} / \text { day or } \\
150 \mathrm{mg} / \text { day vs. placebo for } 26 \text { weeks } \\
484 \text { included in mITT analysis }\end{array}$ & $\begin{array}{l}\Delta \text { from BL in avg. daily \# } \\
\text { of mod/severe HFs at } \\
\text { weeks } 4 \text { and } 12 \\
\Delta \text { from BL in avg. daily } \\
\text { HF severity at weeks } 4 \\
\text { and } 12 \\
2^{\circ} \text { : } \\
\Delta \text { from BL in \# of night- } \\
\text { time awakenings due to } \\
\text { HFs } \\
\text { Important AEs/SAEs } \\
\text { Discontinuation due to } \\
\text { AEs }\end{array}$ & 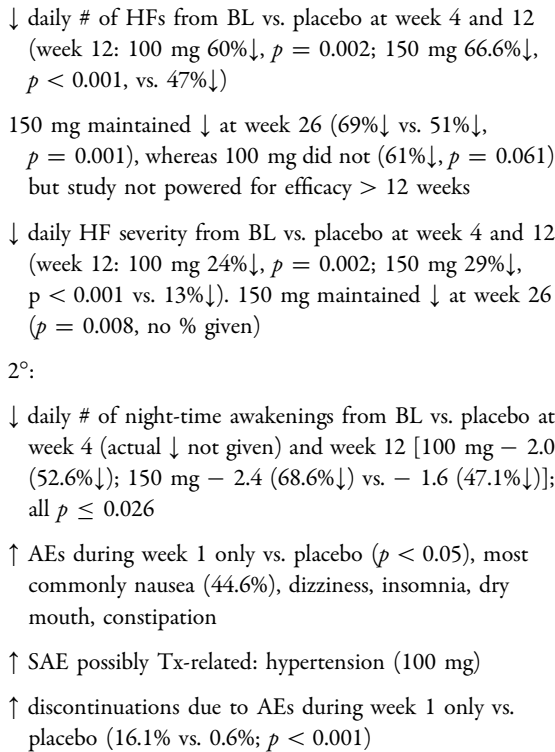 \\
\hline
\end{tabular}


Table 4 continued

\begin{tabular}{|c|c|c|c|}
\hline Clinical trial & Trial design and key participant BL data & Key outcomes & Results ( $p$ values vs. placebo) \\
\hline $\begin{array}{l}5 \\
\text { Bouchard et al } \\
\text { Climacteric (2012) } \\
\quad[24]\end{array}$ & $\begin{array}{l}\text { 12-week DBRCT: } 35 \text { European centres, } 2 \text { centres in South } \\
\text { Africa, } 1 \text { centre in Mexico } \\
\text { Mean age }=53.6 \text { years ( } 40-66 \text { years) } \\
\text { Mean BMI }=26 \mathrm{~kg} / \mathrm{m}^{2}(16-34) \\
\geq 485 \mathrm{randomised}(1: 1: 1) \text { to desvenlafaxine } 100 \mathrm{mg} / \text { day, } \\
\text { tibolone } 2.5 \mathrm{mg} / \text { day, vs. placebo for } 12 \text { weeks } \\
451 \text { included in mITT analysis }\end{array}$ & $\begin{array}{l}1^{\circ}: \\
\Delta \text { from BL in avg. daily \# } \\
\text { of mod/severe HFs at } \\
\text { weeks } 4 \text { and } 12 \\
\Delta \text { from BL in avg. daily } \\
\text { HF severity at weeks } 4 \\
\text { and } 12 \\
2^{\circ}: \\
\text { Important AEs/SAEs } \\
\text { Discontinuation due to } \\
\text { AEs }\end{array}$ & $\begin{array}{l}\text { No } \downarrow \text { in daily \# of HFs from BL vs. placebo at week } 4 \\
(-4.63 \text { vs. }-4.38, p=0.558) \text { and week } 12(-5.78 \\
(57.7 \% \downarrow) \text { vs. }-5.82(57.5 \% \downarrow), p=0.921] \\
\text { No } \downarrow \text { in daily HF severity from BL vs. placebo at week } 4 \\
(-0.37 \text { vs. }-0.31, p=0.352) \text { and week } 12[-0.61 \\
(26.8 \% \downarrow) \text { vs. }-0.61(26.5 \% \downarrow), p=0.943] \\
2^{\circ} \text { : } \\
\uparrow \text { AEs with desvenlafaxine vs. tibolone and placebo (73.4\% } \\
\text { vs. } 64.5 \% \text { and } 55.9 \% \text {, respectively), most commonly } \\
\text { nausea (31\%), dizziness and constipation } \\
\uparrow \text { bleeding with tibolone vs. desvenlafaxine and placebo } \\
\quad[23 \% \text { vs. } 12 \%(p=0.024) \text { and } 9 \% \text { ( } p=0.001), \\
\text { respectively] } \\
\uparrow \text { discontinuations due to AEs during week } 1 \text { only vs. } \\
\text { placebo }(p<0.001) \text {. Most commonly nausea (8.9\%) and } \\
\text { headache }(3.8 \%)\end{array}$ \\
\hline $6 \mathrm{a}$ & 52-week DBRCT: 122 US and Canadian centres & $1^{\circ}:$ & $1^{\circ}:$ \\
\hline $\begin{array}{l}\text { Pinkerton et al } \\
\text { Menopause (2013) } \\
\text { [25] }\end{array}$ & $\begin{array}{l}\text { Mean age }=54 \text { years }(45-71) \\
\text { Mean BMI }=26.45 \mathrm{~kg} / \mathrm{m}^{2}(16.9-35.3) \\
396 \text { randomised (1:1) to desvenlafaxine } 100 \mathrm{mg} / \text { day vs. } \\
\text { placebo for } 52 \text { weeks }(50 \mathrm{mg} / \text { day for } 1 \text { week, titrated to } \\
100 \mathrm{mg} / \text { day for } 51 \text { weeks) } \\
2 \text { week dose-tapering } \\
365 \text { included in mITT analysis } \\
\text { Pinkerton et al. (2013) [25] reports } 12 \text {-week data from an } \\
\text { efficacy substudy (part of a larger } n=2186 \text { safety study) }\end{array}$ & $\begin{array}{l}\Delta \text { from BL in avg. daily \# } \\
\text { of mod and severe HFs } \\
\text { at weeks } 4 \text { and } 12 \\
\Delta \text { from BL in avg. daily } \\
\text { HF severity scores at } \\
\text { weeks } 4 \text { and } 12 \\
2^{\circ} \text { : } \\
\text { Important AEs/SAEs } \\
\text { Discontinuation due to } \\
\text { AEs }\end{array}$ & $\begin{array}{l}\downarrow \text { daily \# of HFs vs. placebo at week } 4[-6.5 \text { HFs }(55 \% \downarrow) \\
\text { vs. }-3.6(31 \% \downarrow) ; p<0.001] \text { and week } 12[-7.3 \text { HFs } \\
(62 \% \downarrow) \text { vs. }-4.5(38 \% \downarrow) ; p<0.001] \\
\downarrow \text { daily HF severity score vs. placebo at week } 4[-0.47 \\
(20 \% \downarrow) \text { vs. }-0.19(8 \% \downarrow) ; p<0.001] \text { and week } 12 \\
{[-0.59(25 \% \downarrow) \text { vs. }-0.28(12 \% \downarrow) ; p<0.001]} \\
2^{\circ} \text { : } \\
\uparrow \text { AEs vs. placebo during week } 1 \text { only ( } p<0.001) \text {, mostly } \\
\text { nausea, dry mouth, constipation (but no diff. in BP) } \\
2 \text { SAEs: } 1 \text { squamous cell carcinoma, } 1 \text { multi-event SAE } \\
\text { (altered mental status with slurred speech, uncontrolled } \\
\text { hypertension, resolved hypokalemia, polypharmacy) } \\
\uparrow \text { discontinuations due to AEs vs. placebo (10.0\% vs. 3.7\%; } \\
p=0.016) \text {; rates similar after week } 1\end{array}$ \\
\hline $\begin{array}{l}\text { Pinkerton et al. } \\
\text { Menopause } \\
\text { (2013) [26] }\end{array}$ & $\begin{array}{l}\text { Pinkerton et al. (2013) [26] reports } 52 \text {-week data from the } \\
\text { same efficacy substudy population } \\
\text { See above }\end{array}$ & $\begin{array}{l}1^{\circ}: \\
\Delta \text { from BL in avg. daily \# } \\
\text { of HFs at weeks } 12,26, \\
52 \\
\Delta \text { from BL in avg. daily } \\
\text { HF severity scores at } \\
\text { weeks } 12,26,52 \\
2^{\circ}: \\
\text { Important AEs/SAEs } \\
\text { Discontinuation due to } \\
\text { AEs }\end{array}$ & $\begin{array}{l}\downarrow \text { in daily \# of HFs at } 12 \text { weeks }[-7.5 \text { HFs }(64 \% \downarrow) \text { vs. } \\
-5.0(43 \% \downarrow) ; p<0.001], 26 \text { weeks }[-8.6 \mathrm{HFs}(74 \% \downarrow) \\
\text { vs. }-6.3(54 \% \downarrow) ; p<0.001 \text { and } 52 \text { weeks }[-7.7 \mathrm{HFs} \\
(66 \% \downarrow) \text { vs. }-4.8(41 \% \downarrow) ; p<0.001] \\
\downarrow \text { in daily HF severity score at } 12 \text { weeks }[-0.63(27 \% \downarrow) \text { vs. } \\
\quad-0.3(13 \% \downarrow) ; p<0.001], 26 \text { weeks }[-0.85(36 \% \downarrow) \text { vs. } \\
-0.53(22 \% \downarrow) ; p=0.001] \text { and } 52 \text { weeks }[-0.75 \\
\quad(32 \% \downarrow) \text { vs. }-0.44(19 \% \downarrow) ; p=0.003] \\
\left.2^{\circ} \text { : includes efficacy substudy ( } n=365\right) \text { and larger safety } \\
\text { population }(n=2186) \\
\uparrow \text { AEs vs. placebo (84\% vs. } 79 \% \text {; } p=0.006) \text {, most } \\
\text { commonly nausea (21\%), headache, dry mouth and } \\
\text { insomnia. Rates of new-onset AEs were similar by week } 3 \\
\text { SAEs: No excess CV ischaemic events vs. placebo over } 52 \\
\text { weeks } \\
\uparrow \text { discontinuations due to AEs vs. placebo (18.3\% vs. } 9.7 \% \text {; } \\
p<0.001) \text {; rates highest during week } 1\end{array}$ \\
\hline
\end{tabular}


Table 4 continued

\begin{tabular}{|c|c|c|c|}
\hline Clinical trial & Trial design and key participant $\mathrm{BL}$ data & Key outcomes & Results ( $p$ values vs. placebo) \\
\hline $7 \mathrm{a}$ & DBRCT: 3 US centres & $1^{\circ}:$ & $1^{\circ}:$ \\
\hline \multirow{3}{*}{$\begin{array}{l}\text { Joffe et al } \\
\text { JAMA Internal } \\
\text { Medicine }\end{array}$} & Mean age $=54.6$ years & \multirow{2}{*}{$\begin{array}{l}\text { Mean daily \# of HFs at } \\
\text { weeks } 4 \text { and week } 8\end{array}$} & \multirow{2}{*}{$\begin{array}{c}\downarrow \# \text { of HFs from BL vs. placebo at week } 4(48 \% \downarrow \text { vs. } 25 \% \downarrow \\
p=0.005) \text { and week } 8(48 \% \downarrow \text { vs. } 29 \% ; p=0.005)\end{array}$} \\
\hline & \multirow{4}{*}{$\begin{array}{l}\text { Mean } \mathrm{BMI}=28.3 \mathrm{~kg} / \mathrm{m}^{2} \\
339 \text { randomised }(2: 2: 3) \text { to venlafaxine XR } 75 \mathrm{mg} / \text { day } \\
(37.5 \mathrm{mg} / \text { day titrated to } 75 \mathrm{mg} / \text { day over } 1 \text { week), oral } \\
\text { 17-beta-oestradiol (ET) } 0.5 \mathrm{mg} / \text { day or placebo for } 8 \\
\text { weeks }\end{array}$} & & \\
\hline & & $2^{\circ}:$ & $2^{\circ}$ : baseline or $\% \downarrow$ data not reported \\
\hline$(2014)[27]$ & & HF severity at week 8 & $\begin{array}{l}\downarrow \text { HF severity vs. placebo at week } 8 \text { (mean diff. vs. placebo } \\
-02 p=0.02 \text { ) }\end{array}$ \\
\hline & & \multirow{4}{*}{$\begin{array}{l}\text { Discontinuation due to } \\
\text { AEs }\end{array}$} & $\uparrow$ AEs vs. ET and placebo $69 \%$ vs. $56 \%$ and $62 \%$, \\
\hline & Venlafaxine followed by 2-week dose-tapering & & respectively; $p=\mathrm{ns}$ ), most commonly fatigue \\
\hline & \multirow[t]{2}{*}{330 included in mITT analysis } & & $\begin{array}{l}12 \text { developed } \mathrm{SBP}>165 \mathrm{mmHg} \text { or } \mathrm{DBP}>95 \mathrm{mmHg} \\
(10.4 \% \text { venlafaxine, } 2.1 \% \mathrm{ET}, 0 \text { placebo), but all had } \mathrm{BL} \\
\text { SBP or DBP }>\text { study population mean. Vaginal bleeding } \\
8.2 \% \mathrm{ET}, 0 \% \text { venlafaxine, and } 1.6 \% \text { placebo }\end{array}$ \\
\hline & & & $\begin{array}{l}\uparrow \text { discontinuations due to AEs vs. placebo (5 venlafaxine, } 4 \\
\text { ET, } 2 \text { placebo; } p=\mathrm{ns} \text { ) }\end{array}$ \\
\hline \multirow{6}{*}{$\begin{array}{l}7 \mathrm{~b} \\
\text { Cann et al } \\
\text { Menopause } \\
(2015)[28]\end{array}$} & \multirow{6}{*}{$\begin{array}{l}\text { Cann et al. [28] reports questionnaire endpoints from Joffe } \\
\text { et al. [27] }\end{array}$} & \multirow{4}{*}{$\begin{array}{l}\text { MENQoL total and } \\
\text { domain scores } \\
\text { Measure of pain (PEG), } \\
\text { depression (PHQ-9) } \\
\text { and anxiety (GAD-7) }\end{array}$} & $\downarrow$ (improved) mean total MENQoL score from BL vs. \\
\hline & & & $\begin{array}{l}\text { placebo at week } 4 \text { and week } 8 \text { (week } 8:-0.9 \text { vs. }-0.7 \\
p=0.042 \text { ) }\end{array}$ \\
\hline & & & Only sig. diff. vs. placebo in psychosocial domain (week 8 \\
\hline & & & -1.5 vs. $-1.3, p=0.008)$ \\
\hline & & \multirow[t]{2}{*}{ Perceived stress (PSS) } & $\begin{array}{l}\text { No improvements vs. placebo with respect to changes in } \\
\text { pain (PEG), depressive symptoms (PHQ-9) or anxiety } \\
\text { (GAD-7) at weeks } 4 \text { and } 8\end{array}$ \\
\hline & & & $\begin{array}{l}\downarrow \text { (improved) perceived stress vs. placebo at week } 4 \text { and } \\
\text { week } 8 \text { (week 8: }-3.4 \text { vs. }-2.0, p=0.02 \text { ) }\end{array}$ \\
\hline
\end{tabular}

$D B R C T$ double-blind, randomised, placebo-controlled trial, $X R$ extended release, mod moderate, \# number, $H F$ s hot flushes/flashes, $V M S$ vasomotor symptoms, $\geq$ greater than or equal to, $\leq$ less than or equal to, $>$ greater than, $<$ less than, $m g / d$ milligrams/day, $(m) I T T$ (modified) intention-to-treat, $B L$ baseline, $I^{\circ}$ primary, $2^{\circ}$ secondary, avg. average, $\Delta$ change, sig. significant, $n s$ not significant, $\uparrow$ increase, $\downarrow$ reduced, diff. difference, $T x$ treatment, (S)AEs (serious) adverse events, $(S)$ or $(D) B P$ (systolic) or (diastolic) blood pressure, $L F T s$ liver function tests, $A L T$ alanine aminotransferase, $A S T$ aspartate aminotransferase, NASH non-alcoholic steatohepatitis, ULN upper limit of normal, MENQ ${ }^{\circ}$ Menopause-Specific Quality of Life questionnaire, HFRDIS Hot Flash-Related Daily Interference Scale, PEG The Pain Enjoyment of Life and General Activity scale, PHQ-9 9-item Patient Health Questionnaire, GAD-7 7-item Generalized Anxiety Disorder questionnaire, PSS Perceived stress scale

observed regarding generalisability and trial design which are important to note in order to place overall results in context and to consider when evaluating differences between treatment groups.

\section{Age}

HF symptoms are typically most severe around the final menstrual period. While mean age in the SNRI (53-55 years) and NK3Ra (54-55 years) trials was similar, the range was much greater in the SNRI trials (29-78 years vs. 41-65 years). This is relevant since it is unknown if treatment is equally effective in all menopause phases.

\section{Ethnicity}

Studies have shown ethnicity to affect HF prevalence with the highest frequency in
Turkish women (97\%) and the lowest in South American (47\%) and Asian (45\%) women [1]. Most SNRI trials predominately $(\sim 75-80 \%)$ recruited Caucasian women from North American centres which is a limitation since HF frequency can vary by population, often less in Asians, but greater in African-Americans [35]. NK3Ra trial participants were mainly Caucasian with few Asians, although an ongoing trial with fezolinetant is recruiting Asian women (NCT04234204) and a trial is planned in Chinese women (NCT04793204).

\section{Menopause Definition}

It is preferable to exclude perimenopausal women since symptoms might improve secondary to fluctuating hormone levels but be mistakenly attributed to the study drug. The 
Table 5 Neurokinin 3 receptor antagonists (NK3Ra) study results

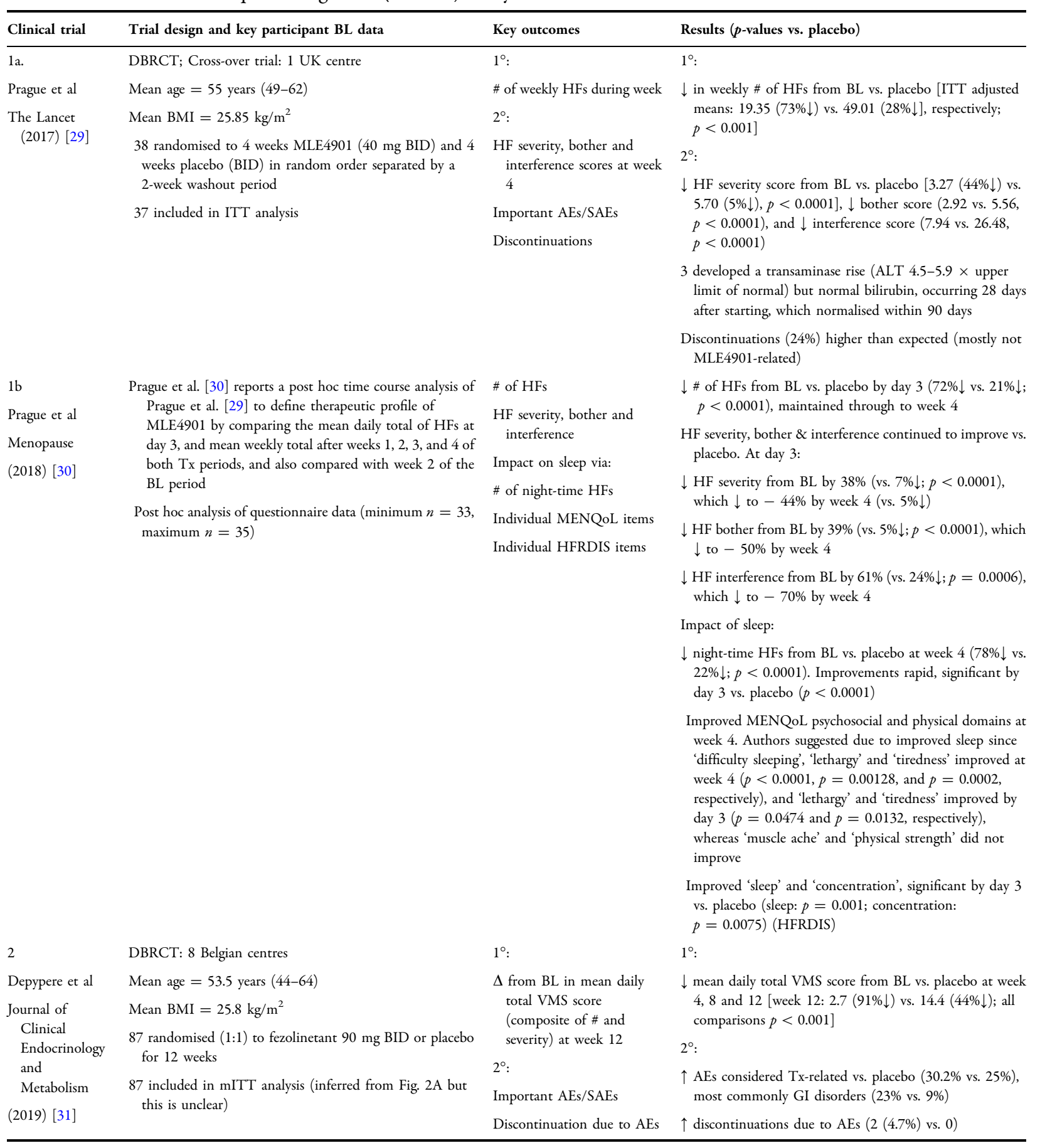


Table 5 continued

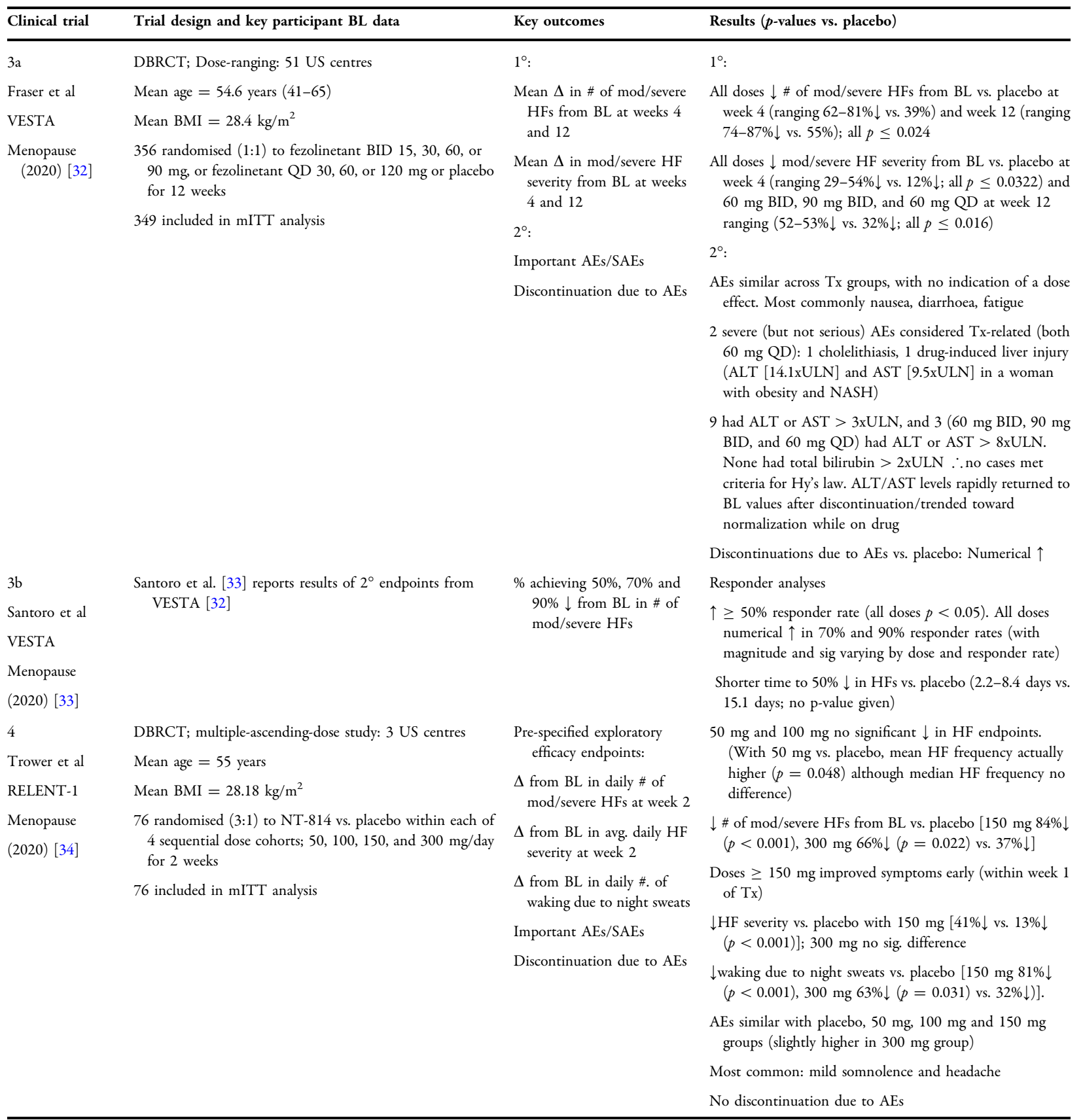

DBRCT double-blind, randomised, placebo-controlled trial, $X R$ extended release, mod moderate, \# number, $H F$ s hot flushes/flashes, $V M S$ vasomotor symptoms, $\geq$ greater than or equal to, $\leq$ less than or equal to, $>$ greater than, $<$ less than, $m g / d$ milligrams/day, $(m) I T T$ (modified) intention-to-treat, $B L$ baseline, $I^{\circ}$ primary, $2^{\circ}$ secondary, avg average, $\Delta$ change, sig. significant, $n s$ not significant, $\uparrow$ increase, $\downarrow$ reduced, diff. difference, $T x$ treatment, $(S) A E s$ (serious) adverse events, $(S)$ or $(D) B P$ (systolic) or (diastolic) blood pressure, $L F T s$ liver function tests, $A L T$ alanine aminotransferase, $A S T$ aspartate aminotransferase, NASH non-alcoholic steatohepatitis, ULN upper limit of normal, MENQoL Menopause-Specific Quality of Life questionnaire, HFRDIS Hot Flash-Related Daily Interference Scale, PEG The Pain Enjoyment of Life and General Activity scale, PHQ-9 9-item Patient Health Questionnaire, GAD-7 7-item Generalized Anxiety Disorder questionnaire, PSS Perceived stress scale 
FDA [36] advise using the following menopause definition: 12 months spontaneous amenorrhea, or 6 months amenorrhea plus $\mathrm{FSH}>40 \mathrm{mIU} / \mathrm{ml}$, or 6 weeks post-surgical menopause. Two SNRI trials did not appear to fulfil the FDA definition and thus could have included perimenopausal women [20, 24]. All NK3Ra trials fulfilled the FDA definition, apart from Depypere et al. [31] who allowed amenorrhea $\geq 3$ months if FSH $>40 \mathrm{IU} / \mathrm{L}$ and oestradiol $<0.21 \mathrm{nmol} / \mathrm{L}$ (which usually indicates premature ovarian insufficiency but oestrogen levels can vary in early stages).

\section{HF Frequency and Severity}

The FDA [36] advise enrolling subjects with $\geq 7$ moderate-severe HFs/day (or $\geq 50 /$ week). All trials fulfilled this except 2 SNRI trials [20, 27] which only required $\geq 14 \mathrm{HFs} /$ week and not all were moderate or severe. Joffe et al. [27] reasoned that by not requiring $\geq 7 \mathrm{HFs}$ /day (which only occurs in 7-9\%), they enrolled a more generalisable population, many of whom do seek HF treatment. However, mild HFs may be less challenging to relieve and thus Joffe's efficacy data could be potentially exaggerated.

\section{HF Stability}

A stable HF pattern is needed to minimise the risk of a spontaneous HF reduction being attributed to a study drug. Most trials required a consistent minimum or $<50 \%$ change in pattern over 1-2 baseline weeks. However, two SNRI trials $[20,21]$ failed to assess baseline stability and hence their results are potentially unreliable. One SNRI trial [23] and one NK3Ra trial [32] required $\geq 50$ HFs over any 7 consecutive days during the 35-day screening period, yet separately used the week prior to randomisation as the baseline comparator, potentially underestimating baseline HF comparisons.

\section{Baseline Characteristics}

Treatment and control groups were generally well balanced. However, Evans et al. [20] reported higher alcohol consumption (a potential HF trigger) in their SNRI group but addressed this using sensitivity analysis. Among NK3Ra trials, Trower et al. [34] reported that the
NT-814 $50 \mathrm{mg}$ group had a higher baseline HF frequency, severity and night-time awakenings which likely accounts for the unexpected observation of $50 \mathrm{mg}$ showing less reduction in HFs compared to placebo.

\section{Comorbidity}

All trials recruited 'healthy' women. While safety data for the use of SNRIs in complex patients has been collected elsewhere, it will be important to establish efficacy and safety of NK3Ras in complex patients during phase 3 or post-market registry settings.

\section{Washout of Prior HF Treatment}

To avoid potential confounding effects, the FDA [36] advises different HRT washout periods depending on administration route. However, a washout was not specified in one SNRI trial [20], and too short a washout was used for one SNRI [27] and one NK3Ra trial [31], thus a spill-over effect may have occurred.

\section{Placebo Control}

The inclusion of a placebo arm comparator was validated after a marked reduction in HF frequency was noted after placebo administration in trials [SNRI range (across all 7 trials) 25-58\%; NKR3a range 28-55\%]. One method to attenuate a large placebo response may be to specify increased HF bother or a similar lifestyle measure as an inclusion criterion. Pinkerton et al. [25], for example, which had the lowest placebo response at week 12 , required a score of $\geq 12$ on the Greene Climacteric Scale (a standard questionnaire assessing physical and psychological menopausal symptoms) at study entry.

\section{Power and Sample Size}

All SNRI trials undertook a power calculation, except Evans et al. [20] which may have been underpowered as the reduction in HF frequency of 1.4 /day was not statistically significant $(p=0.06)$, despite a statistically significant reduction in patient-perceived severity score. Initial NK3Ra trials lacked prior efficacy data to estimate treatment effect but instead used power calculations based on the ability to detect a treatment effect double the 
anticipated $\sim 25 \%$ placebo effect [29] or based on previous HF diary trials [31]. Fraser et al. [32] powered based on prior NK3Ra efficacy [31], but, due to drop-out, failed to achieve the planned 40 subjects in $7 / 8$ groups which may have affected 12-week HF severity evaluation (in which only 3 groups showed a significant reduction). Trower et al. [34] based sample size on a previous pilot study suggesting 8 subjects per group was adequate, but since the $150 \mathrm{mg}$ group achieved all primary endpoints, the failure of $300 \mathrm{mg}$ to show a statistically significant reduction in HF severity at week 12 may have been due to being underpowered.

\section{HF Recording}

All but three trials used retrospective paper diaries to assess HF frequency and severity. However, errors in compliance are major sources of bias and backfilling is common [37]. Prospective time-stamped electronic diaries may give superior timeliness and completion versus paper diaries [37] and were used in three trials $[29,31,32]$. Encouraging respondents to report HFs as they occur (as in one NK3Ra trial [29]), rather than at the end of the day/the following morning, also reduces recall bias.

\section{Estimating Night Sweats}

Use of the 'number of night-time awakenings' in SNRI [21-23] and NK3Ra trials [34] is problematic. Night-sweats may not produce full awakenings and may be under-reported. Disparity between subjective and objective reporting widens at night [38]. Thus, questionnaires such as MENQoL, which evaluate sleep quality [28, 30, 31, 33] may be useful since improved scores in 'concentration', 'difficulty sleeping', 'tiredness' and 'lethargy' correlate with HF therapeutic benefit and may more accurately reflect the impact on participants' lives.

\section{Discontinuation}

If patient drop-out is high, statistical power may be lost. With SNRI trials, early discontinuation due to AEs, often due to nausea, was common (5-29\%), especially during week 1 . When treating depression, SNRIs are usually titrated over 1-2 months to reduce AEs [39]. It is surprising that only four of seven SNRI trials $[20,22,25,27]$ used titration and, even in those trials that did, the titration was very rapid (over 1 week) [22, 27]. In NK3Ra trials, early discontinuation due to AEs was uncommon (5-7\%). Since HFs can continue for 12 years [4], longer trials with SNRIs and NK3Ras are warranted to evaluate long-term efficacy and tolerability/ safety.

\section{SNRI Tolerability and Safety}

Most SNRI trials were short ( $\leq 12$ weeks), apart from two trials which extended to 26 and 52 weeks, albeit with high dropout rates $[23,26]$. Higher-dose SNRIs have been associated with treatment-emergent hypertension (likely due to increased potentiation of noradrenergic neurotransmission). A significant or numerical increase in blood pressure was reported in three SNRI trials [21, 22, 27], although none was powered to evaluate this endpoint (Table 4). A 1-year CV safety study among 2118 subjects with HFs [40] and pooled data from $>6000$ subjects receiving desvenlafaxine for various indications [21] did not report a significant excess of $\mathrm{CV}$ events but 1 year may be too short; the Framingham Heart Study showed an association between $\sim 10 \mathrm{mmHg}$ increase in blood pressure and increased $\mathrm{CV}$ events took 4-6years to emerge [41].

\section{NK3Ra Tolerability and Safety}

Since only short-duration phase 2 data have been published, it was not possible to fully evaluate NK3Ra tolerability and safety. In two trials, participants taking NK3Ras reported a higher frequency of minor GI disorders [31, 32], which could be related to NK3R expression in the GI tract [42]. However, the AE incidence did not appear dose-dependent. Somnolence was also more common ( $69 \%$ vs. $17 \%)$ with the highest (300 mg) dose of NT-814 [34] likely due to its additional NK1Ra action [43]. Interestingly, this could be an advantage for women with sleep disturbance. Asymptomatic rises in transaminases $>3$ times the upper limit of normal were reported with MLE4901 [29] and fezolinetant [32] but bilirubin did not rise $>2$ 
times upper limit of normal. Liver function tests (LFTs) returned to normal after drug discontinuation. However, further safety analyses are required.

\section{Potential Study Bias}

Overall risk of bias was low (Table 3). Selection bias was minimised by randomised study designs. Unreported data leading to potential reporting bias was noted, including pre-specified data on quality of life [21-23, 33], 50\% HF responder rates [21] and apparent differences in gastrointestinal $\mathrm{AE}$ frequency in abstract versus table [31]. Potential conflicts of interest were considered under reporting bias but most trials declared conflicts and often had industry coauthors, which is common for these types of studies. All trials were double-blind (except one [20] using matched placebo) which should have reduced performance bias and detection bias, although this is difficult to fully exclude. One SNRI trial included an HRT arm [24] in which subjects experienced significant bleeding compared with the desvenlafaxine or placebo groups which likely unblinded treatment allocation. High drop rates of $>20 \%$ occurred in several trials $[20,21,23,24,26,29]$ leading to potential attrition bias [44], although this risk was reduced by appropriate use of intention-totreat (ITT) or modified ITT rather than per-protocol analysis for primary outcomes.

\section{Potential Additional Benefits of NK3Ra}

\section{Onset of Therapeutic Effect}

Prague et al. [30] reported symptom improvement after $\sim 48 \mathrm{~h}$ with NK3Ras, with maximum effect by day 3 . Thus, NK3Ras would be expected to give earlier symptom relief versus SNRIs, especially given the slow dose titration recommended for SNRIs.

\section{Sleep Quality/Concentration}

Improved sleep \pm concentration was noted in three NK3Ra trials [30, 31, 34]. This is likely attributed to multiple factors including reduced sleep disruption from HFs, and the attenuation of NK3R actions in melanin-concentrating hormone neurons (involved in the sleep-wake cycle) and in the prefrontal cortex, an important area for concentration [45], whereas the additional NK1Ra action of NT-814 may attenuate substance P-induced arousal and facilitate sleep [43]. In contrast, SNRIs are non-sedating [46], hence a reduction in night-time awakening with SNRIs is likely due to HF reduction and anxiolysis.

\section{Mood}

SNRIs improve depressed mood (another common menopausal symptom). Although it is unclear if NK3Ras directly affect mood, the NK1Ra action of NT-814 may be of benefit [47]. In addition to pharmacotherapy, it may also be worth considering cognitive behavioural therapy (CBT) if mood is a particularly limiting symptom, as the positive effects of CBT appear to be sustained over time [48].

\section{Safety}

After menopause, CV risk increases. In contrast to SNRIs which may be associated with hypertension leading to increased CV risk (discussed above), NK3Ras in rats reversed spontaneous hypertension and lowered heart rate [49] via reducing midbrain dopaminergic signalling in the ventral tegmental area that highly expresses NK3Rs [50]. Vasopressin neurones also express NK3Rs [51], and NKB activity is potentiated by thromboxane A2 [52] which might also represent useful therapeutic targets for NK3Ras.

\section{Limitations of This Analysis}

Conclusions of our qualitative analysis are limited by published data for NK3Ra being only phase 2 trials. Longer duration phase 3 trials are ongoing, and findings will provide further insights into efficacy and safety outcomes [53]. Availability of phase 3 NK3Ra data would also facilitate meta-analysis, enabling determination of a weighted pooled estimate for HF reduction in NK3Ra versus SNRI trials, although the ideal trial to compare NK3Ras versus SNRIs for reduction of menopausal HFs would be a large phase 3 head-to-head trial. 


\section{CONCLUSIONS}

Menopausal HFs can significantly impact a woman's quality of life, but some women cannot or do not wish to take HRT to alleviate their symptoms. Current non-hormonal options are suboptimal due to variable efficacy and low tolerability. The recent discovery that NKBNK3R signalling is implicated in the generation of menopausal HFs has led to recent clinical trials using NK3Ras. Qualitative analysis of these trials indicates that NK3Ras lead to greater reductions in mean HF frequency, HF severity and night-sweats with good short-term tolerability compared to SNRIs. Efficacy and safety data (including careful evaluation of LFTs) from phase 3 trials are awaited with interest.

\section{ACKNOWLEDGEMENTS}

Funding. No funding or sponsorship was received for this study or publication of this article.

Authorship. Both authors meet the International Committee of Medical Journal Editors (ICMJE) criteria for authorship for this article, take responsibility for the integrity of the work as a whole, and have given their approval for this version to be published.

Author Contributions. Both authors contributed to the study conception and design. Material preparation, data collection and analysis were performed by SJM. The first draft of the manuscript was written by SJM. Both authors read and approved the final manuscript.

Disclosures. Sara J Menown and Javier A Tello have no conflicts to disclose.

Compliance with Ethics Guidelines. This article is based on previously conducted studies and does not contain any studies with human participants or animals performed by any of the authors.
Open Access. This article is licensed under a Creative Commons Attribution-NonCommercial 4.0 International License, which permits any non-commercial use, sharing, adaptation, distribution and reproduction in any medium or format, as long as you give appropriate credit to the original author(s) and the source, provide a link to the Creative Commons licence, and indicate if changes were made. The images or other third party material in this article are included in the article's Creative Commons licence, unless indicated otherwise in a credit line to the material. If material is not included in the article's Creative Commons licence and your intended use is not permitted by statutory regulation or exceeds the permitted use, you will need to obtain permission directly from the copyright holder. To view a copy of this licence, visit http:// creativecommons.org/licenses/by-nc/4.0/.

\section{REFERENCES}

1. Makara-Studzińśka MT, Kryś-Noszczyk KM, Jakiel G. Epidemiology of the symptoms of menopause-an intercontinental review. Menopause Rev/Przegląd Menopauzalny. 2014;13(3):203-11.

2. Avis NE, Crawford SL, Greendale G, Bromberger JT, Everson-Rose SA, Gold EB, et al. Duration of menopausal vasomotor symptoms over the menopause transition. JAMA Intern Med. 2015;175(4): 531-9.

3. Stearns V, Ullmer L, López JF, Smith Y, Isaacs C, Hayes D. Hot flushes. Lancet. 2002;360(9348): 1851-61.

4. National Institute for Health and Care Excellence (NICE). Menopause: diagnosis and management [NG23] [Internet]. 2015. https://www.nice.org.uk/ guidance/ng23. Accessed 11 Aug 2021.

5. Rossouw JE, Anderson GL, Prentice RL, LaCroix AZ, Kooperberg C, Stefanick ML, et al. Risks and benefits of estrogen plus progestin in healthy postmenopausal women: principal results from the Women's Health Initiative randomized controlled trial. JAMA. 2002;288(3):321-33.

6. Stuenkel CA, Davis SR, Gompel A, Lumsden MA, Murad $\mathrm{MH}$, Pinkerton JV, et al. Treatment of symptoms of the menopause: an endocrine society 
clinical practice guideline. J Clin Endocrinol Metab. 2015;100(11):3975-4011.

7. Royal College of Obstetricians and Gynaecologists. Alternatives to HRT for the Management of Symptoms of the Menopause [Scientific Impact Paper No. 6] [Internet]. 2010. https://www.rcog.org.uk/ globalassets/documents/guidelines/scientificimpact-papers/sip_6.pdf. Accessed 18 Feb 2021.

8. Topaloglu AK, Tello JA, Kotan LD, Ozbek MN, Yilmaz MB, Erdogan S, et al. Inactivating KISS1 mutation and hypogonadotropic hypogonadism. N Engl J Med. 2012;366(7):629-35.

9. Moore AM, Coolen LM, Porter DT, Goodman RL, Lehman MN. KNDy cells revisited. Endocrinology. 2018;159(9):3219-34.

10. Skorupskaite K, George JT, Anderson RA. The kisspeptin-GnRH pathway in human reproductive health and disease. Hum Reprod Update. 2014;20(4):485-500.

11. Krajewski SJ, Burke MC, Anderson MJ, McMullen NT, Rance NE. Forebrain projections of arcuate neurokinin $\mathrm{B}$ neurons demonstrated by anterograde tract-tracing and monosodium glutamate lesions in the rat. Neuroscience. 2010;166(2):680-97.

12. Rance NE, Dacks PA, Mittelman-Smith MA, Romanovsky AA, Krajewski-Hall SJ. Modulation of body temperature and LH secretion by hypothalamic KNDy (kisspeptin, neurokinin B and dynorphin) neurons: a novel hypothesis on the mechanism of hot flushes. Front Neuroendocrinol. 2013;34(3): 211-27.

13. Baber RJ, Panay N, Fenton A. 2016 IMS recommendations on women's midlife health and menopause hormone therapy. Climacteric. 2016;19(2):109-50.

14. Woyka J. Consensus statement for non-hormonal based treatments for menopausal symptoms. Post Reprod Health. 2020;26(3):137-41.

15. Moher D, Liberati A, Tetzlaff J, Altman DG. Preferred reporting items for systematic reviews and meta-analyses: the PRISMA statement. BMJ. 2009;339:b2535.

16. Freeman EW, Ensrud KE, Larson JC, Guthrie KA, Carpenter JS, Joffe H, et al. Placebo improvement in pharmacologic treatment of menopausal hot flashes: time course, duration, and predictors. Psychosom Med. 2015;77(2):167-75.

17. Critical Appraisal Skills Programme. CASP Randomised Controlled Trials Checklist [Internet]. 2019. https://casp-uk.net/casp-tools-checklists/. Accessed 11 Aug 2021.
18. Higgins JPT, Altman DG, Sterne JAC (editors). Chapter 8: Assessing risk of bias in included studies. In: Higgins JPT, Churchill R, Chandler J, Cumpston MS (editors), Cochrane Handbook for Systematic Reviews of Interventions version 5.2.0 (updated June 2017) [Internet]. 2017. https://training. cochrane.org/handbook. Accessed 11 Aug 2021.

19. Lensen S, Archer D, Bell RJ, Carpenter JS, Christmas M, Davis SR, et al. A core outcome set for vasomotor symptoms associated with menopause: the COMMA (Core Outcomes in Menopause) global initiative. Menopause. 2021. https://doi.org/10. 1097/GME.0000000000001787.

20. Evans ML, Pritts E, Vittinghoff E, McClish K, Morgan KS, Jaffe RB. Management of postmenopausal hot flushes with venlafaxine hydrochloride: a randomized, controlled trial. Obstet Gynecol. 2005;105(1):161-6.

21. Speroff L, Gass M, Constantine G, Olivier S. Efficacy and tolerability of desvenlafaxine succinate treatment for menopausal vasomotor symptoms: a randomized controlled trial. Obstet Gynecol. 2008;111(1):77-87.

22. Archer DF, Seidman L, Constantine GD, Pickar JH, Olivier S. A double-blind, randomly assigned, placebo-controlled study of desvenlafaxine efficacy and safety for the treatment of vasomotor symptoms associated with menopause. Am J Obstetr Gynecol. 2009;200(2):172.e1-.e10.

23. Archer DF, Dupont CM, Constantine GD, Pickar JH, Olivier S. Desvenlafaxine for the treatment of vasomotor symptoms associated with menopause: a double-blind, randomized, placebo-controlled trial of efficacy and safety. Am J Obstetr Gynecol. 2009;200(3):238.e1-.e10.

24. Bouchard P, Panay N, De Villiers TJ, Vincendon P, Bao W, Cheng RJ, et al. Randomized placebo- and active-controlled study of desvenlafaxine for menopausal vasomotor symptoms. Climacteric. 2012;15(1):12-20.

25. Pinkerton JV, Constantine G, Hwang E, Cheng RFJ. Desvenlafaxine compared with placebo for treatment of menopausal vasomotor symptoms: A 12-week, multicenter, parallel-group, randomized, double-blind, placebo-controlled efficacy trial. Menopause. 2013;20(1):28-37.

26. Pinkerton JV, Archer DF, Guico-Pabia CJ, Hwang E, Cheng RFJ. Maintenance of the efficacy of desvenlafaxine in menopausal vasomotor symptoms: A 1-year randomized controlled trial. Menopause. 2013;20(1):38-46.

27. Joffe H, Guthrie KA, LaCroix AZ, Reed SD, Ensrud $\mathrm{KE}$, Manson JE, et al. Low-dose estradiol and the 
serotonin-norepinephrine reuptake inhibitor venlafaxine for vasomotor symptoms: a randomized clinical trial. JAMA Intern Med. 2014;174(7): 1058-66.

28. Caan B, Lacroix AZ, Joffe H, Guthrie KA, Larson JC, Carpenter JS, et al. Effects of estrogen and venlafaxine on menopause-related quality of life in healthy postmenopausal women with hot flashes: a placebo-controlled randomized trial. Menopause. 2015;22(6):607-15.

29. Prague JK, Roberts RE, Comninos AN, Clarke S, Jayasena CN, Nash Z, et al. Neurokinin 3 receptor antagonism as a novel treatment for menopausal hot flushes: a phase 2, randomised, double-blind, placebo-controlled trial. The Lancet. 2017;389(10081):1809-20.

30. Prague JK, Roberts RE, Comninos AN, Clarke S, Jayasena $\mathrm{CN}$, Mohideen $\mathrm{P}$, et al. Neurokinin 3 receptor antagonism rapidly improves vasomotor symptoms with sustained duration of action. Menopause (N Y, NY). 2018;25(8):862-9.

31. Depypere H, Timmerman D, Donders G, Sieprath P, Ramael S, Combalbert J, et al. Treatment of menopausal vasomotor symptoms with fezolinetant, a neurokinin 3 receptor antagonist: a phase $2 \mathrm{a}$ trial. J Clin Endocrinol Metab. 2019;104(12):5893-905.

32. Fraser GL, Lederman S, Waldbaum A, Kroll R, Santoro $\mathrm{N}$, Lee $\mathrm{M}$, et al. A phase $2 \mathrm{~b}$, randomized, placebo-controlled, double-blind, dose-ranging study of the neurokinin 3 receptor antagonist fezolinetant for vasomotor symptoms associated with menopause. Menopause (N Y, NY). 2020;27(4): 382-92.

33. Santoro N, Waldbaum A, Lederman S, Kroll R, Fraser GL, Lademacher C, et al. Effect of the neurokinin 3 receptor antagonist fezolinetant on patient-reported outcomes in postmenopausal women with vasomotor symptoms: results of a randomized, placebo-controlled, double-blind, dose-ranging study (VESTA). Menopause (N Y, NY). 2020;27(12):1350-6.

34. Trower M, Anderson RA, Ballantyne E, Joffe H, Kerr M, Pawsey S. Effects of NT-814, a dual neurokinin 1 and 3 receptor antagonist, on vasomotor symptoms in postmenopausal women: a placebo-controlled, randomized trial. Menopause (N Y, NY). 2020;27(5): 498-505.

35. Gold EB, Colvin A, Avis N, Bromberger J, Greendale GA, Powell L, et al. Longitudinal analysis of the association between vasomotor symptoms and race/ethnicity across the menopausal transition: study of women's health across the nation. Am J Public Health. 2006;96(7):1226-35.
36. US Department of Health and Human Services, Food and Drug Administration, Center for Drug Evaluation and Research. Guidance for industryestrogen and estrogen/progestin drug products to treat vasomotor symptoms and vulvar and vaginal atrophy symptoms-recommendations for clinical evaluation [Internet]. 2003. https://www.fda.gov/ media/71359/download. Accessed 28 Feb 2021.

37. Stone AA, Shiffman S, Schwartz JE, Broderick JE, Hufford MR. Patient compliance with paper and electronic diaries. Control Clin Trials. 2003;24(2): 182-99.

38. Regestein QR. Hot flashes and sleep. Menopause. 2006;13(4):549-52.

39. Electronic medicines compendium [Internet]. 2021. https://www.medicines.org.uk/emc/. Accessed 11 Aug 2021.

40. Archer DF, Pinkerton JV, Guico-Pabia CJ, Hwang E, Cheng RFJ. Cardiovascular, cerebrovascular, and hepatic safety of desvenlafaxine for 1 year in women with vasomotor symptoms associated with menopause. Menopause. 2013;20(1):47-56.

41. Vasan RS, Larson MG, Leip EP, Evans JC, O'Donnell CJ, Kannel WB, et al. Impact of high-normal blood pressure on the risk of cardiovascular disease. N Engl J Med. 2001;345(18):1291-7.

42. Jaafari N, Hua G, Adélaïde J, Julé Y, Imbert J. Expression of the tachykinin receptor mRNAs in healthy human colon. Eur J Pharmacol. 2008;599(1-3):121-5.

43. Ratti E, Carpenter DJ, Zamuner S, Fernandes S, Squassante L, Danker-Hopfe $\mathrm{H}$, et al. Efficacy of vestipitant, a neurokinin-1 receptor antagonist, in primary insomnia. Sleep. 2013;36(12):1823-30.

44. Schulz KF, Grimes DA. Sample size slippages in randomised trials: exclusions and the lost and wayward. Lancet. 2002;359(9308):781-5.

45. Cvetkovic V, Poncet F, Fellmann D, Griffond B, Risold PY. Diencephalic neurons producing melanin-concentrating hormone are influenced by local and multiple extra-hypothalamic tachykininergic projections through the neurokinin 3 receptor. Neuroscience. 2003;119(4):1113-45.

46. Wichniak A, Wierzbicka A, Walęcka M, Jernajczyk W. Effects of antidepressants on sleep. Curr Psychiatry Rep. 2017;19(9):63.

47. Ratti E, Bettica P, Alexander R, Archer G, Carpenter $D$, Evoniuk G, et al. Full central neurokinin-1 receptor blockade is required for efficacy in depression: evidence from orvepitant clinical studies. J Psychopharmacol. 2013;27(5):424-34. 
48. Hunter MS. Cognitive behavioral therapy for menopausal symptoms. Climacteric. 2021;24(1): 51-6.

49. Lessard A, Campos MM, Neugebauer W, Couture R. Implication of nigral tachykinin NK3 receptors in the maintenance of hypertension in spontaneously hypertensive rats: a pharmacologic and autoradiographic study. Br J Pharmacol. 2003;138(4):554-63.

50. De Brito GH, Couture R. Blockade of tachykinin NK3 receptor reverses hypertension through a dopaminergic mechanism in the ventral tegmental area of spontaneously hypertensive rats. Br J Pharmacol. 2010;161(8):1868-84.
51. Pineda R, Sabatier N, Ludwig M, Millar RP, Leng G. A direct neurokinin $\mathrm{B}$ projection from the arcuate nucleus regulates magnocellular vasopressin cells of the supraoptic nucleus. J Neuroendocrinol. 2016;28:4.

52. Pal S, Wu J, Murray JK, Gellman SH, Wozniak MA, Keely PJ, et al. An antiangiogenic neurokinin-B/ thromboxane A2 regulatory axis. J Cell Biol. 2006;174(7):1047-58.

53. Prague JK. Neurokinin 3 receptor antagonistsprime time? Climacteric. 2021;24(1):25-31. 